\title{
Histiocytosis: An Uncommon Presentation with Hypopituitarism
}

\author{
Kota SK ${ }^{1}$, Jammula S' , Tripathy PB ${ }^{3}$, Kota $\mathrm{SK}^{4}$, Meher LK ${ }^{5}$, Modi K ${ }^{6}$ \\ 'Dr. Sunil Kumar Kota, Department of Endocrinology, Medwin Hospital, Hyderabad, Andhra Pradesh, India, ${ }^{2}$ Sruti Jammula \\ Department of Pharmaceutics, Roland Institute of Pharmaceutical Sciences, Berhampur, Orissa, India, ${ }^{3}$ Prabhas Ranjan \\ Tripathy, Department of Anatomy, Kalinga Institute of Medical Sciences, Bhubaneswar, Orissa, India, ${ }^{4}$ Siva Krishna Kota \\ Department of Anaesthesia, Central Security Hospital, Riyadh, Saudi Arabia, ${ }^{5}$ Dr. Lalit Kumar Meher, MD (Medicine) Head, \\ Department of Medicine, MCKG Medical College, Berhampur, Orissa, India, ${ }^{6}$ Dr. Kirtikumar D Modi, Head, Department of \\ Endocrinology, Medwin Hospital, Hyderabad, Andhrapradesh, India.
}

Address for correspondence: Dr. Sunil Kumar Kota, E-mail hidocsunil@ibibo.com

\begin{abstract}
Langerhans cell histiocytosis is a multi system disorder with a certain predilection for involving hypothalamic pituitary axis. We hereby report a 7 year old girl presenting with polyuria, polydipsia and growth retardation. The girl had a past history of pain in right hip joint and nodular region over chest. Water deprivation test confirmed the diagnosis of central diabetes inspidus. Other investigations revealed Growth hormone deficiency and central hypothyroidism. X-ray and MRI hip revealed absent right inferior pubic ramus with bone marrow biopsy confirming the diagnosis of histiocytosis. Patient was treated with nasal Arginine Vasopressin spray, subcutaneous growth hormone and oral thyroxine.
\end{abstract}

Key words: Histiocytosis, Diabetes inspidus, Growth hormone deficiency, Central hypothyroidism

\section{Introduction}

angerhans' cell histiocytosis (LCH) is a rare disease Lwith an annual incidence of 4 per million for the age range median in children above 3 years of age ${ }^{1}$. The granulomatous deposits consisting of specific langerhan's dendritic cells occur at multiple sites within the body and involve hypothalamic pituitary axis (HPA) in $5-50 \%$ cases $^{2}$. Diabetes inspidus (DI) is the most common endocrine abnormality in $15-50 \%$ cases $^{3}$ with anterior pituitary dysfunction in $5-20 \%$ cases $^{4}$. We hereby report a case of a girl child with histiocytosis presenting with DI and partial hypopituitarism.

\section{The Case}

A 7 year old girl presented with complaints of excessive thirst with thirst persisting during night, frequent urination including nocturia for six months. There was no associated altered mental status. Additionally she complained of lethargy, dry skin, cold intolerance and constipation. Three years before, she had a history of painful nodular chest lesion on ribs and pain in hip joints following which X-ray pelvis (Figure 1) and MRI hip revealed absent right inferior pubic ramus. $\mathrm{X}$ ray skull revealed multiple radioluscent lesions (Figure
2). Bone marrow biopsy revealed infiltration with diffuse large foamy histiocytes, large Langerhan's giant cells with abundant cytoplasm and lymphocytic aggregates and fibrosis with occasional red blood cells confirming the diagnosis of histiocytosis (Figure 3). She was treated by chemotherapy for 2 months followed by radiotherapy for 2 months. 1 year later the parents noticed that she is gradually lagging behind in height from her peers and the younger sibling has surpassed her sister. Her scholastic performance was good.

She is product of nonconsanguineous marriage delivered by cesarian section at term. Antenatally mother had pregnancy induced hypertension. She had normal physical and mental milestones with adequate dietary intake $(1200 \mathrm{~K}$ cal diet with 20 grams protein and $800 \mathrm{mg}$ calcium per day). There was no history suggestive of raised intracranial tension, chronic illness or malabsorption.

On examination patient appeared well hydrated with normal vital parameters. Her height was $108 \mathrm{~cm}$ ( $<3^{\text {rd }}$ percentile, height age-5 years 6 months) as per Agarwal growth chart for Indian children with weight $23 \mathrm{~kg}\left(75^{\text {th }}\right.$ percentile, weight age- 9 years). Her pubertal 
staging was $\mathrm{Bl}, \mathrm{PI}$. There was no goiter, midline or any other skeletal deformity, rash, bony pain, bony swellings over gum/ mandible, seborrhea ear discharge. Systemic examination including CNS was normal.

Investigations revealed serum sodium $138 \mathrm{meq} / \mathrm{L}$, potassium $4.5 \mathrm{meq} / \mathrm{L}$, chloride $140 \mathrm{meq} / \mathrm{L}$, bicarbonate $20 \mathrm{meq} / \mathrm{L}$, blood urea nitrogen $18 \mathrm{mg} / \mathrm{dl}$, creatinine- 0.6 $\mathrm{mg} / \mathrm{dl}$ and serum osmolality was $290 \mathrm{mosm} / \mathrm{kg}$. Twenty four hour urine volume was 5 litres ad urine osmolality was $220 \mathrm{mosm} / \mathrm{kg}$. Fluid deprivation test was carried out for 4 hours with monitoring for conditions that might provide ono osmotic stimuli for vasopressin secretion (nausea, hypotension, vasovagal reaction). Also serial evaluation of body weight, cardiovascular stability, serum sodium was done. Urine osmolality in mosm/ $\mathrm{kg}$ at each hour were as follows, $1^{\text {st }}$ hour- $230,2^{\text {nd }}$ hour$270,3^{\text {rd }}$ hour- $280,4^{\text {th }}$ hour-300. The test was stopped at 4 hours because the urine osmolality remained stable (3 consecutive urine sample osmolalities varied by $<30 \mathrm{mosm} / \mathrm{kg})^{5}$. The plasma osmolality at 4 hours was $29 \mathrm{mosm} / \mathrm{kg}$. Desmopressin $(0.1 \mathrm{mg})$ was given subcutaneously and urine osmolality was measured at 30, 60, 120 minutes thereafter. These values were 350, 420, $460 \mathrm{mosm} / \mathrm{L}$ respectively confirming the diagnosis of central diabetes inspidus. $X$ ray hand for bone age by Greulich Pyle's method was 5 year 6 months._Other laboratory parameters were cortisol-10.4 $\mu \mathrm{g} / \mathrm{dl}, \mathrm{ACTH}-$ $20 \mathrm{pg} / \mathrm{ml}, \mathrm{T}_{4}-3.6 \mu \mathrm{g} / \mathrm{dl}, \mathrm{TSH}-1.1 \mu \mathrm{lU} / \mathrm{ml}$, prolactin- $15 \mu \mathrm{g} /$ dl. Stimulated growth hormone levels following insulin $(1.2 \mathrm{U}$ ie $0.05 \mathrm{IU} / \mathrm{Kg}$ ) was $1.5 \mathrm{ng} / \mathrm{ml}$ at 60 minutes and 2.3 $\mathrm{ng} / \mathrm{ml}$ at 90 minutes. MRI brain revealed normal pituitary.

With the above mentioned picture, a diagnosis of central diabetes inspidus, partial hypopituitarism (growth hormone deficiency and central hypothyroidism) due to histiocytosis was established. Patient was treated with subcutaneous $\mathrm{rGH} 0.3 \mathrm{mg} / \mathrm{kg} /$ week at night given at a frequency of 7 days/ week, thyroxine replacement 50 $\mu \mathrm{g}$ orally daily and calcium supplementation. Arginine vasopressin nasal spray in a concentration of $0.1 \mathrm{mg} / \mathrm{ml}$ was prescribed at a dose of 1 spray 3 times daily

\section{Discussion}

Literature mentions that despite treatment nearly $20 \%$ patients with multisystem involvement have a progressive disease course ${ }^{6}$. Similar was the scenario in our case, where the girl progressed to develop diabetes inspidus and partial hypopituitarism.

Stage III A of LCH leads to pituitary involvement ${ }^{7}$. The LCH cases with pituitary involvement reported in the literature had diabetes inspidus and most had panhypopituitarism ${ }^{8}$. DI is the most common endocrine abnormality encountered and in most cases it is complete. However, partial forms of DI may also occur and remit spontaneously ${ }^{9}$. In our patient it was complete and central in origin. Although DI may predate the diagnosis of LCH it develops most commonly at about 12 months with a range of many years from diagnosis 9 .

Anterior pituitary deficiency in LCH is almost associated with $\mathrm{Dl}^{2}$; only a few cases with anterior pituitary dysfunction without $\mathrm{DI}$ have been reported ${ }^{10}$. GHD occurs in approximately $40 \%$ of affected children, and it has been related to histiocytic infiltration of the hypothalamus ${ }^{11}$. GHD has frequently been observed as the first endocrine defect in addition to DI. Others have found it only in relation to treatment with radiotherapy ${ }^{12}$. Similarly, thyroid hormone deficiency can be a major component of anterior pituitary dysfunction in patients with $\mathrm{LCH}^{9}$. Some have described primary hypothyroidism due to $\mathrm{LCH}$ infiltration of the thyroid gland $^{6}$. ACTH deficiency mostly presented in the context of generalized pituitary involvement; however, a case of isolated ACTH deficiency has also been described 9 . Our patient had GHD with central hypothyrodism with normal serum cortisol and ACTH levels.

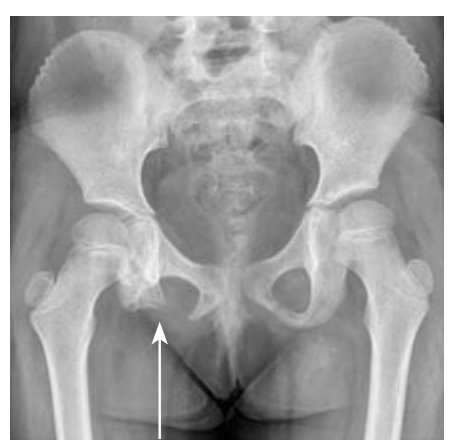

Fig 1: $X$ ray of the pelvis showing absent right inferior pubic ramus.

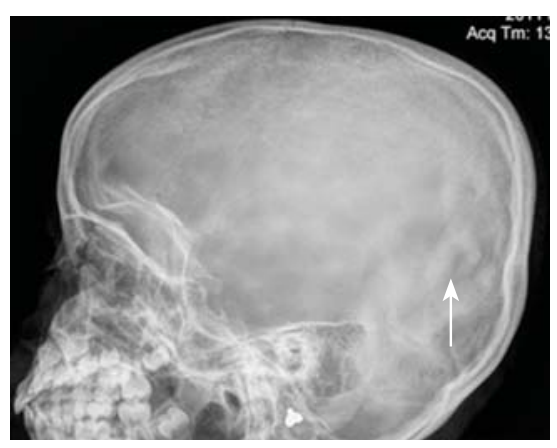

Fig 2: $\mathrm{X}$ ray skull revealing multiple radioluscent lesions

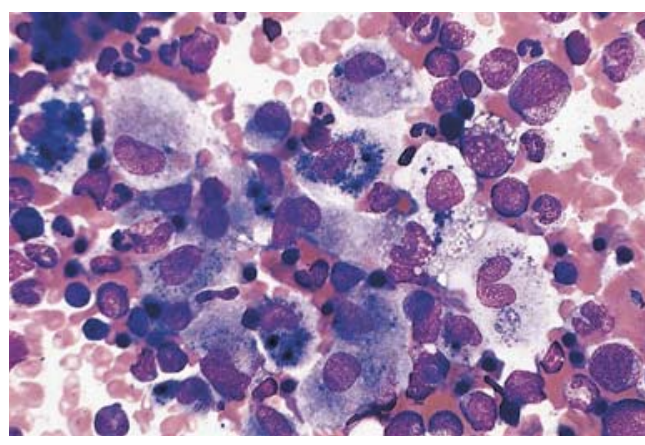

Fig 3: Photomicrograph showing Bone marrow biopsy revealing diffuse large foamy histiocytes, large Langerhan's giant cells with abundant cytoplasm and lymphocytic aggregates and fibrosis with occasional red blood cells. (H\& E Stain.) 
In addition abnormalities of the HPA were observed in $68 \%$ of patients with CNS lesions and in $81.5 \%$ of patients with DI (infundibular thickening, partial or complete empty sella with a lack of posterior pituitary bright spot on T1-weighted MRI sequences, or a pituitary mass lesion) ${ }^{2}$. A small pituitary or empty sella has also been described in cases of combined anterior and posterior pituitary insufficiency ${ }^{9}$. In our case there was no pituitary abnormalities in the MRI. Anterior pituitary dysfunction in the absence of structural changes on imaging could be attributed to microinjury leading to vascular impairment and scarring ${ }^{11}$. Other possible mechanisms include cytokine modulation from adjacent osseous lesions or an autoimmune effect ${ }^{13}$. Kaltsas et al have reported elevated prolactin levels in LCH patients, which was unlikely to be associated with hypogonadotropic hypogonadism ${ }^{6}$. Prolactin level was normal in our patient.

DI with structural changes in the HPA often heralds the involvement of other parts of the brain with more global neurological or neuropsychological sequelae, depending on the location of the involvement ${ }^{2}$. The signs and symptoms of nonendocrine hypothalamic (NEH) involvement range from disturbances in social behavior, appetite, and temperature regulation to abnormal sleeping patterns ${ }^{2}$. Kaltsas et al have found a high prevalence of NEH abnormalities in patients with $\mathrm{DI}$ and $\mathrm{LCH}$; all were associated with anterior pituitary deficiency and structural lesions on imaging. The most prominent abnormality was an abnormal eating pattern and obesity; five patients developed morbid obesity, which was difficult to control ${ }^{6}$. Further abnormalities, such as disturbances in thermoregulation and adipsia, can make DI difficult to treat and complicate the overall management of these problematic cases ${ }^{14}$. No such abnormalities were noted in our subject.

Maghnie et al. attempted to identify predictors' of late endocrine sequelae in children with $\mathrm{LCH}$ and concluded that dynamic endocrine pituitary testing was not a useful predictor ${ }^{11}$. Neither the site of involvement nor the extent of the disease was associated with further endocrine deterioration. Therefore, it seems that only DI in association with markedly abnormal HPA imaging indicates patients with $\mathrm{LCH}$ at higher risk for anterior pituitary dysfunction. As DI is associated with multisystem disease in the majority of studies ${ }^{9}$, and progression may be greatly delayed ${ }^{15}$, such patients should be receiving regular and prolonged follow-up to identify such dysfunction and provide adequate replacement.

\section{Conclusion}

Endocrine abnormalities like diabetes inspidus and panhypopituitarism should be actively and periodically sought in patients with Langerhans cell histiocytosis as their recognition and management plays an important role in the treatment of this difficult condition.

\section{References}

1. Krutchkoff DJ, Jones CR. Multifocal eosinophilic granuloma: a clinical pathologic conference. J Oral Pathol 1984;13:472-88.

2. Grois N, Favara B, Mostbeck H, Prayer D. Central nervous disease in Langerhans cell histiocytosis. Hematol Oncol Clin North Am 1998;12:287-97.

3. Malpas SJ. Langerhans cell histiocytosis in adults. Hematol Oncol Clin North Am 1998;12:259-68.

4. Willis B, Ablin A, Weinberg V, Zoger S, Wara WM, Matthay KK. Disease course and late sequelae of Langerhans cell histiocytosis: 25 years experience at the University of California, San Francisko. J Clin Oncol 1996;14:2073-82.

5. Manrique C, Lastra G, Whaley-Connell A, Sowers JR. Clinical disorders of vasopressin. In: Lavin N. Manual of Endocrinology and metabolism, $4^{\text {th }}$ edn, Lippincott Williams \& Wilkins. 2009; 60-75.

6. Kaltsas GA, Powles TB, Evanson J, Plowman PN, Drinkwater JE, Jenkins PJ, Monson JP, Besser GM, Grossman AB. Hypothalamic pituitary abnormalities in adult patients with Langerhans cell histiocytosis: clinical, endocrinological and radiological features and response to treatment. J Clin Endocrinol Metab 2000;85:1370-76.

7. Eben OB. Oncology and terminal care. In: Campbell AG, Mclntosh (eds). Forfar and Arneil's textbook of pediatrics, $4^{\text {th }}$ edn, Edinburgh. Churchill Livingstone. 1992;1001-2.

8. Howarth DM, Gilchrist GS, Mullan BP, Wiseman GA, Edmonson JH, Schomberg PJ. Langerhans cell histiocytosis: diagnosis, natural history, management and outcome. Cancer 1999;85:227890.

9. Broadbent V, Dunger D, Yeomans E, Kendall B. Anterior pituitary function and computed tomography/ magnetic resonance imaging in patients with Langerhans cell histiocytosis and diabetes inspidus. Med Pediatr Oncol 1993;21:649654.

10. Balaguruswamy S, Chattington PD. Partial Hypopituitarism and Langerhans cell histiocytosis. BMJ Case Reports 2011; doi: 10. 1136/ bcr.07.2010.3203. 
11. Maghnie M, Bossi G, Klersy C, Cosi G, Genovese E, Arico M. Dynamic endocrine testing and magnetic resonance imaging in the long term follow-up of childhood Langerhans cell histiocytosis. J Clin Endocrinol Metab 1998;83:3089-94.

12. Dean HJ, Bishop A, Winter JSD. Growth hormone deficiency in patients with histiocytosis X. J Pediatr 1986;109:615-18.

13. Catalina PF, Rodriguez GM, de la Torre C, Paramo C, Garcia-Mayor RV. Diabetes insipidus for five years preceding the diagnosis of hypothalamic Langerhans cell histiocytosis. J Endocrinol Invest $1995 ; 18: 663-66$.

14. Burn DJ, Watson JD, Roddie M, Chu AC, Legg NJ, Frackowiak RS. Langerhans' cell histiocytosis and the nervous system. J Neurol 1992;239:345-50.

15. Kilpatrick SE, Wenger DE, Gilchrist GS, Shives TC, Wollan PC, Unni KK. Langerhans' cell histiocytosis (histiocytosis X) of bone. Cancer 1995;76:2471-84.

\section{How to cite this article?}

Kota SK, Jammula S, Tripathy PB, Kota SK, Meher LK, Modi K. Histiocytosis: An Uncommon Presentation with Hypopituitarism. J Nepal Paediatr Soc 2012;32(1):81-84. 